\title{
The Influence of Self-Compassion, Religiosity, Support Group, and Income to Subjective Well-Being of Parents Caring Children with Intellectual Disability
}

\author{
Risa Dwi Ratnasari ${ }^{1}$, Neneng Tati Sumiati ${ }^{2}$ \\ Risa.wiratnas@gmail.com ${ }^{1}$, Neneng.tati@yahoo.co.id ${ }^{2}$ \\ Faculty of Psychology Syarif Hidayatullah State Islamic University Jakarta
}

\begin{abstract}
Subjective well-being (SWB) is an evaluation of a person's cognitive and affective life. Evaluation of one's life in subjective well-being includes a positive emotional reaction to the occurrence in life, as well as the lack of negative emotional charge of cognition ratings on satisfaction and fulfillment in life [13]. This study was conducted to determine the influence of self-compassion, religiosity, support group and income on the subjective well-being of parents of children with ID (intellectual disability). Researcher adapting various instruments such as Diener's SWB instrument [11], [13], Neff's self-compassion instrument [25], and Huber's religiosity instrument [20]. The research method used a non-probability sampling with accidental sampling technique. Participants in this study amounted to 209 parents. The researcher uses Confirmatory Factor Analysis (CFA) as construct validity test. The results showed that the four dimensions, namely self-compassion, religiosity,support group, and income have a significant effect on subjective well-being of parents who have children with intellectual disability around Jakarta and Tangerang city of Indonesia. The proportion of the overall independent variables towards SWB amounted to $28.8 \%$ with four significant variables that self-compassion, religiosity in aspects of religious knowledge, religious Group and household income.
\end{abstract}

Keywords: Subjective Well-Being, Self-Compassion, Religiosity, Support Group, Income.

\section{INTRODUCTION}

Parents who have children with intellectual disability is faced with an unusual life. The dependence of people with disabilities caused by their limitations makes quite demands that have a direct impact on both the psychological and physical health of the caregiver [39]. Moreover, the maladaptive behavior caused by people with intellectual disability creates stress conditions for parents who have children with intellectual disability. Based on comparative research Subjective well-being (SWB), between parents who have children with intellectual disability and parents who have non- disability children showed a significant difference in the subjective Well-being parents, where higher depression and anxiety scores resulted in lower subjective well-being scores in parents with children with intellectual disability compared with non-disability-born parents [4]. 
Subjective well-being is defined as a person's cognitive and affective evaluation of his or her life. Evaluation of a person's life in subjective well-being includes positive emotional reactions to the events in life, low negative emotional loads as well as a cognitive assessment of satisfaction and fulfillment [13].

In a preliminary study conducted by researchers on a number of parents who have children with intellectual disability in 2016 obtained, the majority of responses reflect the negative feelings caused by the presence of children with intellectual disability. Negative feelings like sadness, confusion, anxiety, and shock are quite profound. There is also a concern about the future and the independence of the children when parents are gone and anxiety because the child becomes a victim of bullying in the home environment.

Low SWB conditions in parents are certainly not good for the care and life sustainability of children with intellectual disability because parents are the main providers of support for the children, maintaining good health and well-being of the parents is a must in order to provide optimal care for children [3].

Based on Neff's [27] research on subjective well-being, there are factors that play a role in improving the scores of subjective well-being in personal. One of the factors that contribute to subjective well-being is self-compassion. Self- compassion can be understood as a personal's emotional regulatory strategy for dealing with difficult situations through awareness of self-affection, understanding and openness to the environment [26] In the same study it was also suggested that "parenting and support that accompanied by self-compassion can help parents to reduce their fatigue in the face of raising a child with autism disorder" [30].

The other factor that can increase subjective well-being is religiosity. Based on the research of Witter, Stock, Okun, and Haring [43] toward religiosity and subjective well-being variables can be concluded that religiosity has a significant relationship to subjective wellbeing in adults in the United State [43].

Then become a member of a support group that has the same condition of which having children with special needs can also contribute to subjective well-being parents who have children with intellectual disability. Parents who participated in the support group were reported to have more adaptive coping and greater satisfaction in receiving information benefits than parents who did not participate in the support group [7].

From the results of the initial study on the same sample, obtained a positive response from the perceived impact on participation in a support group of parents of children with intellectual disability. Positive responses include making the mind healthier, not feeling alone, calm and happy. Further explained by some parents that the participation in the support group to make parents have a place to share the joys and sorrows about their children, easier to deal with the problem of children, feel to have many friends and no longer need to feel ashamed to have children with intellectual disability.

In line with the literature above on the review conducted by the researcher to parents with intellectual disability children also showed almost all positive responses to parental participation in the support group. On the other hand, the family's financial factor is also a factor that can improve subjective well-being. As found in the study of Aditya [2] that income is one of the variables that have a significant influence on subjective well-being in parents who have ASD (Autism Spectrum Disorder) [2].

Researchers assume parents who have high self-compassion, good religious beliefs and the participation in special support groups or communities will result in a high subjective well-being, as well as high household income that impact on the presence of a positive assessment and parental satisfaction To their life, the researcher decided to raise the title 
"The influence of self-compassion, religiosity, support group, and income to parents' subjective well-being of children with intellectual disability".

\section{RESEARCH METHOD}

\section{Population, sample, and sampling method}

The population in this study were parents of intellectual disability children who live in Jakarta and Tangerang, amounted to 230 people and then through the elicitation process data obtained by participants of 209 people. There are also sample characteristics as follows:

1. A father or mother who has children with intellectual disability.

2. The said children in the age range of toddlers to junior high.

3. Domiciled in Tangerang and Jakarta.

4. Have a child with an intellectual disability disorder.

Researchers use a non-probabilitysampling technique, which is accidental sampling.

\subsection{Research Instrument}

There are four standard measurement scales and two demographic information used by the researcher in this research, they are:

1. Subjective well-being instrument

In the measurement of subjective well- being, the researcher used two adapted scales, to measure the cognitive aspects the researcher using Diener et.al [11] SWLS (Satisfaction With Life Satisfaction Scale) which consists of 5 items that are favorable and for affective aspects researcher used Diener et . Al [13] SPANE (Scale of Positive and Negative Group) consists of 12 items in which 6 items measure positive effects and 6 items measure negative affects.

2. Self-compassion instrument

In the self-compassion measurement, the researchers adapted the self-compassion scale created by Neff [25] containing 26 items consisting of favorable and unfavorable items with 10 items to measure self-kindness vs. self-judgment, 8 items for measuring common humanity vs. isolation, and 8 items to measure mindfulness vs. over-identification.

3. Religiosity instrument

On the measurement of religiosity researcher adapted CRS (Central Religious Scale) developed by Stefan Huber and Odilo Huber [20] containing 15 items consisting of favorable items with details of 3 items measuring religious knowledge, 3 items measuring religious beliefs, 3 items measuring group religious activities, 3 items measure personal religious activity, 3 items measure religious Group.

4. Demographic variables instrument (support group and income)

In the measurement of the support group and income variables, participants are directed to fill in the demographic data on the research scale. 


\section{RESEARCH RESULT}

\section{Regression Analysis}

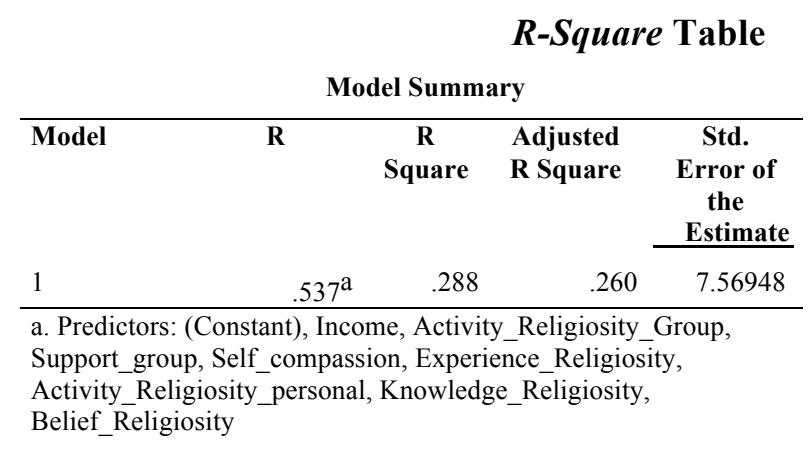

Based on data in the R-Square table, known that the acquisition of R-square is 0.288 or $28.8 \%$. This means that the proportion of variance of Subjective well-being influenced by independent variable is $28.8 \%$, while $71.2 \%$ is influenced by other variables outside this research.

\section{ANOVA IV toward DV}

\begin{tabular}{|c|c|c|c|c|c|c|}
\hline \multicolumn{7}{|c|}{ ANOVA Table } \\
\hline & del & $\begin{array}{c}\text { Sum of } \\
\text { Squares }\end{array}$ & df & $\begin{array}{c}\text { Mean } \\
\text { Square }\end{array}$ & $F$ & Sig. \\
\hline & Regression & 4644.621 & 8 & $\begin{array}{r}580.57 \\
8\end{array}$ & $\begin{array}{r}10.13 \\
3\end{array}$ & $\begin{array}{r}.000 \\
\mathrm{~b}\end{array}$ \\
\hline 1 & Residual & $\begin{array}{r}11459.41 \\
8\end{array}$ & $\begin{array}{r}20 \\
0\end{array}$ & 57.297 & & \\
\hline & Total & $\begin{array}{r}16104.03 \\
8\end{array}$ & $\begin{array}{r}20 \\
8\end{array}$ & & & \\
\hline & $\begin{array}{l}\text { ependent Va } \\
\text { redictors: (C } \\
\text { ivity_Religio } \\
\text { compassior } \\
\text { ivity_Religio } \\
\text { ef_Religiosi }\end{array}$ & $\begin{array}{l}\text { riable: SWL } \\
\text { onstant), In } \\
\text { sity_Group } \\
\text {, Experienc } \\
\text { sity_person } \\
\text { ty }\end{array}$ & $\begin{array}{l}\text { Sme, } \\
\text { Supp } \\
\text { Rel } \\
1, \mathrm{Kn}\end{array}$ & $\begin{array}{l}\text { ort_group } \\
\text { igiosity, } \\
\text { owledge }\end{array}$ & Relig & \\
\hline
\end{tabular}

Based on the ANOVA table note that the value of $\mathrm{p}$ ( sig) on the rightmost column is 0.000 or with a value of $p<0.05$. Hence the hypothesis that there is a significant influence of all independent variables on subjective well-being is accepted, meaning that there is a significant influence of Self- compassion, Religious Knowledge, religious belief, group religious activity, religious activity of personal religious Group, support group, and income against subjective well-being. 


\section{Coef regression}

\begin{tabular}{|c|c|c|c|c|c|c|}
\hline & & Un- & Std & Std & & \\
\hline & & $\mathrm{Coe}$ & & Coeff & & \\
\hline & & B & $\begin{array}{l}\text { Std. } \\
\text { Error }\end{array}$ & Beta & & \\
\hline 1 & (Constant) & 13.540 & 4.234 & & 3.198 & .002 \\
\hline & $S C$ & .127 & .064 & .133 & 1.986 & .048 \\
\hline & R.Knowledge & .234 & .104 & .216 & 2.251 & .025 \\
\hline & R.Belief & -.035 & .097 & .035 & -.362 & .718 \\
\hline & $\begin{array}{l}\text { R Gr. } \\
\text { Activities }\end{array}$ & -.032 & .091 & .032 & -.352 & .725 \\
\hline & R Ind. & & & & & \\
\hline & & .107 & .105 & .098 & 1.019 & .309 \\
\hline & R.Group & .268 & .103 & .251 & 2.619 & .010 \\
\hline & Support & & & & & \\
\hline & Group & .040 & 1.058 & .002 & .031 & .910 \\
\hline & Income & 1.024 & .495 & .127 & 2.070 & .040 \\
\hline
\end{tabular}

Based on the table of regression coefficients, it can be seen that there are four significant variables that influence subjective well-being, namely Self- compassion with the significance of 0.048 , religious knowledge with significance of 0.025 , religious Group with significance of and income with significance of 0.040 .

\section{Proportion of Variance}

To see the addition of the variance proportion of each independent variable to subjective well-being. There are eight variables that can be seen each one of every variable proportion, they are:

1. The self-compassion variable has $\mathrm{R}$ Square Change of 0.091 , which means that this aspect contributes $9.1 \%$ to SWB and the contribution is statistically significant because of the value of Sig. F Change $=0.000(p<0.05)$.

2. The religious knowledge variable has $\mathrm{R}$ Square Change of 0.112 , which means that this aspect contributes $11.2 \%$ to SWB and the contribution is statistically significant because of the value of Sig. F Change $=0.000(p<0.05)$.

3. Religious belief variables have R Square Change of 0.023 , which means that this aspect contributes $2.3 \%$ to SWB and the contribution is statistically significant because of the Sig value. F Change $=0.015(\mathrm{p}<0.05)$.

4. The group activity variable has $\mathrm{R}$ Square Change of 0.000 , which means that this aspect has no contribution to SWB and the variable is not statistically significant because of the value of Sig. F Change $=0.972(p>0.05)$. 
5. The variable of personal religious activity has $\mathrm{R}$ Square Change of 0.018 , which means that this aspect contributes $1.8 \%$ to SWB and the contribution is statistically significant because of the value of Sig. F Change $=0.029(p<0.05)$.

6. Religious Group variables have R Square Change of 0.030 , which means that this aspect contributes $3 \%$ to SWB and the contribution is statistically significant because of the value of Sig. F Change $=0.004(\mathrm{p}<0.05)$.

7. The support group variables have R Square Change of 0.000 , which means that this aspect has no contribution to SWB and the contribution is not statistically significant because of the value of Sig. F Change $=0.898(\mathrm{p}>0.05)$.

8. The income variable has $\mathrm{R}$ Square Change of 0.015 , which means that this aspect contributes $1.5 \%$ to SWB and the contribution is statistically significant because of the value of Sig. F Change $=0.040(p<0.05)$.

\section{CONCLUSION}

After hypothesis testing on the result section, the major hypothesis concluding from this research is: "there is a significant influence from self-compassion, religiosity (religious knowledge, religious belief, group religious activity, personal religious activity, Religious Group), support group and income towards parents' subjective well-being who have children with intellectual disability disorder". Based on the results of the F test is that all independent variables are significant toward the dependent variable. $\mathrm{R}$ square gain of 0.288 or $28.8 \%$ indicates the proportion of variant of the independent variable that influences the dependent variable, while $71.2 \%$ is influenced by other variables outside the research.

However, in the minor hypothesis testing the influence of each independent variable to the dependent variable if seen from the significance of the regression coefficient, it is found that there are only four independent variables that have significant regression coefficients. These variables are self-compassion, religiosity in aspects of religious knowledge and religious Group, and household incomes of study participants. While religiosity variable in religious belief aspect, group religious activity, personal religious activity, also variable of group support do not have a significant influence on the subjective well-being of parents who have children with intellectual disability disorder.

\section{DISCUSSION}

This study aims to examine the effect of self-compassion, religiosity, support group, and income toward parents' subjective well-being who have children with intellectual disability. The results of the study found that the variable self- compassion has a significant positive effect on subjective well-being. This finding is in line with Neff's research on the relationship between self-compassion and parents' well- being who have children with autism. In the study, findings stated that the high level of self-compassion in the parents is associated with parents' well-welfare who have children with autism. Also mentioned that self-compassion can be a bidder and character strength in personal distress that often appears in parents who have children with autism [30].

Self-compassion acts as an emotional regulation of an undesirable event in life. A person is encouraged to respond to an event with full awareness of self-understanding of the situation, and acceptance is interpreted as a life lesson [28]. So that the process of 
self- compassion can form a better new perspective on the occurrence Group [27]. Experiencing unexpected events in the study was parents who had children with intellectual disability. It is hard to accept, but by applying self-compassion there will be a faster understanding and acceptance so that parents can have a better new perspective where it is an indication of the high subjective well-being in the parent.

Then on the religiosity variable, the given influence is greater than the contribution of any other variables to the dependent variable. This reflects the aspect of religiosity is very influential, especially in the aspect of religious knowledge and religious Group in improving the subjective well-being of parents who have children with ID. This finding is in line with Diener's research on the influence of religiosity on subjective well-being on national level, showing respondents with a high level of religiosity resulting in a high subjective well-being level in people with difficult lives [17].

The researcher also found the research of religiosity variable especially on the participation of religious activities, based on the findings the researcher stated that religious participation affects negatively towards the subjective well- being of adults in China. Still, in the explanation of his research it can be caused by uncontrolled variables in research such as religion that is used there, the type of religious activity and the intensity of religious activities (Philip H brown \& Brian Tierney, 2006). The same thing with the cause of insignificant influence in religious aspects of religious beliefs and religious activities both personals and groups in this study researcher suspect its due to uncontrolled variables in the study.

Furthermore, in this study, there are two demographic variables that are measured, which are the support group and income. Based on the results of data processing in the previous discussion, it was found that the support group variable has no significant effect on subjective well- being.

The findings of this study contrasted with Yoon's research which suggested a strong influence between social connectedness toward subjective well- being in adults following the Korean immigrant community than those who did not follow immigrant communities (Yoon \& Lee, 2010). This may be due to the difference in samples in which the adult characteristics of the study are not specific to the elderly who have mentally ill children, another thing that can also be explained is the life that is lived by the parent who has a child with ID can not be compared with the adults who are not faced with such conditions, but in this case researcher focus is the same research variables on the role of the support group of immigrant communities against subjective well-being.

In addition, the lack of a support group in this research could be caused by the lack of a secure relationship between parents who follow the support group. Therefore, the usefulness of the support group has not been so felt that it has not been able to become a factor that can improve subjective well-being in the parents.

Meanwhile, in Tessen Clifford's [7] study entitled "Support Groups for Parents of Children with Autism Spectrum Disorders: Predictors and Effects of Involvement" states that parents who participate actively in the parents support group (PSG) have a higher level of satisfaction over the usefulness of more groups and more adaptive coping usage versus parents who never follow PSG and parents who decide not to continue participation in PSG. It was also reported that parents who decided to discontinue participation in PSG were due to the low support of the desired people in the group so that parents felt they did not benefit as parents who actively participated [7]. Based on the exposure of this research can be taken several reasons why the support group in this study has not been able to improve subjective well-being parents who have children with intellectual disability.

The income variable contributes significantly to the parents' subjective well- being who 
have children with intellectual disability. It is undeniable that having children with special needs requires special treatment and needs. The need for special schools, special foods, a therapy that can stimulate the child's life skill, and so forth. The special needs of the child can be met well when supported with adequate financial condition. In one study it was found that income would increase a person's subjective well-being, as long as income could help a person meet his basic needs [14]. Therefore, the better the financial condition of parents who have children with intellectual disability will facilitate parents in meeting the needs of both children and families.

\section{REFERENCE}

[1] Ahuvia, A. C., \& Friedman, D. C., 1998. Income, consumption, and subjective wellbeing:Toward a composite macromarketing model. Journal of macromarketing, 18(2), 153 168.doi:10.1177/02761467980180207.

[2] Adhityani, E., 2014. Pengaruh Optimisme, Religiusitas, dan Dukungan Sosial Terhadap subjective well-being orang tua yang memiliki anak ASD Autism Spectrum Disorder). Universitas Islam Negeri Syarif Hidayatullah Jakarta, 1-20.

[3] Benjak, T., Vuletić Mavrinac, G., \& Pavić Šimetin, I., 2009. Comparative Study on Self-perceived Health of Parents of Children with Autism Spectrum Disorders and Parents of Nondisabled Children in Croatia. Croatian medical journal,50(4), 403409. DOI: $10.3325 / \mathrm{cmj} .2009 .50 .403$.

[4] Boromand, N., Narimani, M., \&Mosazadeh, T., 2014. Comparing the psychological well-being factors among the parents of the mentally retarded children with those of the non-disability children. International Letters of Social and Humanistic Sciences, (21), 18. doi:10.18052/www.scipress.com

[5] Biswas-Diener, R., \& Diener, E., 2001. Will Money Increase Subjective Well being? A Literature Review and Guide to Needed Research. Social Research Indicators, 57, 119 169. DOI:10.1007/97890-4812350 6_6

[6] Calvisi, D., \& Dibble, J., 2011. Well-being in older adults in three different. Grand Valley State University Volume 32, 2016.

[7] Clifford, T., 2011. Support groups for Parents of Children with Autism Spectrum Disorders: Predictors and thesis, 35. Colón-Bacó, E. (2010). The strength of religious beliefs is important for subjective well-being. Undergraduate economic review, 6(1), 11. Retrieved from http://digitalcommons.iwu.edu/uer/ vol6/iss1/11

[8] Cramm, J.M, \& Nieboer, A.P., 2011. Psychological well-being of caregivers of children with intellectual disabilities: Using parental stress as a mediating factor. Journal of Intellectual Disability Research, 15(2), 101-113. DOI:10.1177/1744629511410922

[9] Degutis, M., \& Urbonavicius, S., 2013. Determinants of subjective wellbeing in Lithuania. Engineering Economics, 24(2), 111-118. DOI:10.1007/s11136014-0694-8

[10] Desmet, P. M. A., \& Pohlmeyer, A. E., 2013. Positive design: An introduction to design for subjective well-being. International Journal of Design, 7(3), 5-19

[11] Diener, E., 1984. Subjective well-being. Psychological Bulletin Vol. 95, No. 3, 1984, $542-565$.

[12] Diener, E., Suh, E. M., Lucas, R. E., \& Smith, H. E., 1999. Subjective well- being: Three decades of progress. Psychological Bulletin, 125, 276302.

[13] Diener, E., Oishi, S., \& Lucas, R. E., 2009. Subjective well-being: The scienceof 
happiness and life satisfaction. Oxford handbook of positive psychology, 2, 187-194.

[14] Biswas-Diener, R., \& Diener, E., 2001. Will Money Increase Subjective Well being? A Literature Review and Guide to Needed Research. Social Research Indicators, 57, 119 169. DOI:10.1007/97890-48123506_6

[15] Diener, E., \& Chan, M. Y., 2011. Happy people live longer: Subjective wellbeing contributes to health and longevity. Applied Psychology: Health and Well-Being, 3(1), 143. DOI: $10.1111 / \mathrm{j} .17580854 .2010 .01045 . \mathrm{x}$

[16] Diener, E., Inglehart, R., \& Tay, L., 2013. Theory and validity of life satisfaction scales. Social Indicators Research, 112(3), 497-527. DOI: 10.1007/s11205 0120076-y

[17] Diener, E., Tay, L., \& Oishi, S., 2013. Rising income and the subjective well being of nations. Journal of personality and social psychology, 137, 267. doi:10.1037/a0030487

[18]English, E., 2013. The effect of community participation on subjective well- being in community-dwelling elders. Honors Projects, 1-22.

[19]Hall, C. W., Row, K. A., Wuensch, K. L., \&Godley, K. R., 2013. The role of selfcompassion in physical and psychological well-being. The Journal of Psychology, 147(4),311-323.

[20]Huber, S., \& Huber, O. W., 2012. The centrality of religiosity scale (CRS). Religions, 3(3), 710 724.doi:10.3390/rel3030710

[21]Jacobson, J. W., Mulick, J. A., \& Rojahn, J., 2007. Handbook of Intellectual and Development Disability. New York: Springer Science+Business Media.

[22]Luhmann, M., Hofmann, W., Eid, M., \& Lucas, R. E., 2013. Subjective well- being and Adaptation to Life Events: A Meta-. J Pers Soc Psycho, 3, 592-615. DOI: $10.1037 / \mathrm{a} 0025948$

[23]Matson, J. L., 2007. Handbook of Assessment in Persons with Intellectual Disability. Baton Rouge, Louisiana: Elsevier Inc.

[24]Mattson, M., \& Gibb, H. J., 2011. Linking health communication with social support. in: Health as Communication nexus: A Service- learning approach. Dubuque: Kendall Hunt Publishing Company.

[25]Neff, K. D., 2003. The development and validation of a scale to measure selfcompassion. Self and Identity, 2(3), 223-250 Volume 2, 2003.

[26]Neff, K., 2003. Self-compassion: An alternative conceptualization of a Healthy attitude toward oneself. Self and Identity, 2(2), 85-101.

[27]Neff, K. D., 2004. Self-compassion and psychological well-being. Constructivism in the human sciences, 9(2), 27-37.

[28]Neff, K. D., 2011. Self-compassion, self- esteem, and well-being. Social and personality psychology compassion, 5(1), 1-12.

[29]Neff, K. D., 2012. The science of self- compassion. In C. Germer \& R. Siegel (Eds.), Compassion and Wisdom in Psychotherapy. 79-92

[30]Neff, K. D., \& Faso, D. J., 2015. Self compassion and well-being in parents of children with autism. Mindfulness, 6(4), 938 947.doi:10.1007/s12671-0140359-2

[31]Neff, K. D., 2016. The self-compassion scale is a valid and theoretically coherent measure of self- compassion. Mindfulness, 7(1), 264274. 10.1007/s12671 015-0479-3

[32]NICHCY., 2011. January). Parent to Parents Support. 3nd edition, p. 2.

[33]Nikmat, A. W., Ahmad, M., Oon, N., \& Razali, S., 2008. Stress and psychological wellbeing among parents of children with autism spectrum disorder. ASEAN Journal of Psychiatry, 9(2), 65-72.

[34]Mbugua, M. N., Kuria, M. W., \& Ndetei, D. M., 2011. The prevalence of depression among family caregivers of children with intellectual disability in a rural 
setting in Kenya. International journal of family medicine, 2011. DOI: 10.1155/2011/534513

[35]O’Hara, J., McCarthy, J., \& Bouras, N., 2010. Intellectual Disability and Ill Health. Cambridge: Cambridge University Press.

[36]Paloutzian, R., \& Santrock, J., 2005. Handbook Of the Psychology of Religion and Spirituality. London: The Guildford Press.

[37]Parnami, M., Mittal, U., \& Hingar, A., 2013. Impact of religiosity on subjective well being in various groups: A comparative study. Indian Journal of Health and Wellbeing, 4(4), 903908.

[38]Pavot, W., \& Diener, E., 1993. Review of the satisfaction with life scale Psychological assessment, 5(2), $164 \quad$ 172.doi: 10.1007/s11205012-0076-

[39]Raina, P., O'Donnell, M., Rosenbaum, P., Brehaut, J., Walter, S. D., Russell, D., \&Wood, E., 2005. The health and well-being of caregivers of children with cerebral palsy. Pediatrics, 115(6), 626-636. DOI: 10.1542/peds.2004-1689

[40]Ritzema, A. M., \& Sladeczek, I. E., 2011. Stress in Parents of Children with Developmental Disabilities over Time. Journal on Developmental Disability, 27,21-34. DOI: $10.1111 /$ j.1365-2788.2006.00933

[41]Umar, J., 2011. Analisis konfirmatori. Bahan ajar peminatan psikometri, Tidak diPublikasikan. Fakultas Psikologi Universitas Islam Syarif Hidayatullah Jakarta.

[42]Watson, D., Pichler, F., \& Wallace, C., 2010. Subjective well-being in Europe. Luxembourg: Office for Official Publications of the European Communities.

[43]Witter, R. A., Stock, W. A., Okun, M. A., \& Haring, M. M., 1985. Religion and subjective well being in adulthood: A quantitative synthesis. Review of religious Research,332342.doi.org/0.2307/3 511048

[44]Wolbring, G., 2013. Subjective wellbeing, body-related ability expectations and peace. International Journal of Peace Studies, 29-42. 